\title{
sciendo
}

\section{Research Trends in Marketing Science Before COVID-19 Outbreak: A Literature Review}

\author{
Noveri MAULANA \\ Sekolah Tinggi Manajemen PPM (PPM School of Management), and \\ Postgraduate Program in Management, University of Indonesia \\ Jakarta - Indonesia \\ noverimaulana@gmail.com / noveri.maulana91@ui.ac.id
}

\begin{abstract}
The research trends after COVID-19 pandemic will be changing and more challenging. This study is aimed to review the trends of marketing research in the first semester of 2020. There are three parts of this analysis. First, review was made to summarize the trend of research domain and model. Second, the trend of data collection method is also synthesized. Third, trends of data analysis method are being categorized. Result shows that before COVID-19 outbreak, research model in marketing studies was dominated by Literature Review articles (systematic, integrative, and meta-analysis), and also Experimental Studies on various consumer behaviour topics. In term of data collection methods, Purposive Sampling and Amazon Mechanical Turk (MTurk) are two approaches that popularly used by the researchers. On the trend of data analysis method, ANOVA, Regression, and Qualitative Analysis are three popular methods which used among the studies. Future research agendas after the pandemic are also discussed in this study.
\end{abstract}

Keyword: Research Trends, Research Comparison, Marketing Research, Literature Review, Journal Review, COVID-19 Research.

Please cite the article as follows: Maulana, N., (2020), "Research Trends in Marketing Science Before COVID-19 Outbreak: A Literature Review", Management \& Marketing. Challenges for the Knowledge Society, Vol. 15, No. Special Issue, pp. 514-533, DOI: 10.2478/mmcks-2020-0030.

\section{Introduction}

Novel Corona Virus Disease 2019 (COVID-19) is becoming a pandemic in the world as stated by World Health Organization (WHO) since March 2020. For the first time, this virus was detected in China and becoming an outbreak to other countries in very short time. Hence, this pandemic is impacting the human life, including the business activities (Craven et al., 2020) and global economic situation (Carlsson-Szlezak et al., 2020). Some countries have officially inviting their prominent researchers and experts to develop research regarding the economic development during and after pandemic. Moreover, some academic journals are also inviting the researchers and authors to publish their papers related to the COVID-19 outbreak.

Various articles have been published regarding the COVID-19 topics, such as an analysis regarding the impact of COVID-19 to e-business in Malaysia (Hasanat et al., 2020), and a study which focusing to the role of social media on misinformation regarding COVID-19 in Iran (Bastani \& Bahrami, 2020). Furthermore, a research on predicting the future of medical business is also conducted to prepare the 'new normal' business situation after the pandemic (de Caro et al., 2020). Those researches are some 
evidences that publication regarding COVID-19 topics are interesting and becoming new trend for the research agenda in 2020.

The research trend after COVID-19 pandemic will be changing and more challenging. More researches in health science will be preferred, but in the area of economic, management, and business studies, the impact of COVID-19 is also important to be analysed. In the past two decades, research topic in marketing studies have been developed. For example, some topics which commonly discussed in the marketing related journals in the past few years were about customer satisfaction, branding strategy, marketing innovation, and consumer behaviour (Nicolas et al., 2020). Meanwhile, after COVID-19 outbreak, the impact of pandemic situation to the marketing strategy and consumer behaviour will be also interesting to be empirically analysed.

This is the focus of the paper. COVID-19 outbreak has changing the future trends and research agenda, especially in the area of marketing studies. This study argued that researchers need to understand the previous research trends in marketing studies before the pandemic to build their research agenda after the outbreak. Through an integrative literature review, this study would provide several insights for the development of future research agendas. The diversity of methodological and measurement in the research will contribute to the theorical and practical implementation of the marketing science (Dahlstrom et al., 2008). The more analysis on previous research through a structural literature review, the deeper understanding would be made to the development of any future research agenda. Also, it is important to pay attention to the complementary effects, like intellectual capital and organizational learning (Agoston \& Dima, 2012; Bratianu et al., 2020).

The study on literature review of marketing science has been conducted by many scholars such as Nicolas et al (2020), Sorescu et al (2017), Chabowski et al (2011), and Yang et al (2006). Those researchers have been reviewing various articles which published in the reputable marketing journals in the past decades. Some of the journals in their analysis are Journal of Marketing (JOM), Journal of Academic Marketing Science (JAMS), Journal of Marketing Research (JMR), Journal of Consumer research (JCR), and Marketing Theory (MT). Those five most influential journals in marketing studies are also used as sample in this study. The purposive sampling method is implemented based on the journals' indexing status (indexed in SCOPUS and Web of Science/WOS), and the citation metric (H-Index and Average Citation per Articles). The detail explanation of the journals criteria is described in the Table 1.

Table 1. Criteria of Data Sampling

\begin{tabular}{lccc}
\hline \multicolumn{1}{c}{ Journals } & H-Index & $\begin{array}{c}\text { Avg. citation per } \\
\text { article }\end{array}$ & Indexed \\
\hline Journal of Marketing (JOM) & 244 & 78 & SCOPUS \& WOS \\
\hline $\begin{array}{l}\text { Journal of Consumer Research } \\
\text { (JCR) }\end{array}$ & 177 & 40 & SCOPUS \& WOS \\
\hline $\begin{array}{l}\text { Journal of Marketing Research } \\
\text { (JMR) }\end{array}$ & 162 & 44 & SCOPUS \& WOS \\
\hline $\begin{array}{l}\text { Journal of Academic Marketing } \\
\text { Science (JAMS) }\end{array}$ & 128 & 49 & SCOPUS \& WOS \\
\hline Marketing Theory (MT) & 32 & 12 & SCOPUS \& WOS \\
\hline & & Source: adapted from Nicolas et al (2020)
\end{tabular}

SCOPUS and WOS are the two most popular index databases for journals in the world. Some academic institutions are using SCOPUS and WOS index as their journals reputation measurement (Stojanovski \& Pehar, 2014). Meanwhile, H-index is indicating 
the cumulative impact of the article performance in the journals. The higher $\mathrm{H}$-index number indicate the higher impact the publication to the society. Furthermore, the average citation score is indicating the number of an article in the journals is being cited by other publications. The more citation score it gained is indicating the level of popularity of the articles (Franceschini et al., 2015). Therefore, those five most influencing journals in marketing studies are being selected to be data sample of this literature review.

\section{Methodology}

This literature review analysis is purposively conducted to enhance the knowledge and understanding regarding the trend of research topic, methodology, and future development of marketing science. Snyder (2019) explained that there are several approaches in the literature review methodology which commonly used in social sciences such as systematic literature review, semi-systematic literature review, and integrative literature review.

This study is applying the integrative literature review in its analysis. Unlike the systematic literature review, this integrative review is purposely aimed to assess, critique, and synthesize the previous publications and proposing new concept or framework based on the critical analysis (Snyder, 2019). Therefore, this methodology approach requires the creativity of the researchers to seek references in various perspectives and resources. However, some researches were not clearly transparent on their integrative method. The critical review should be given in a creative and transparent process, which logical argument must be supported by deep analysis. Therefore, contrasting and comparing the articles should be applied and integrated (Snyder, 2019).

The transparent process on collecting articles from the designated journals as sample has been clearly stated in the previous section. However, in conducting literature review methodology, there are several steps which should be followed by the researchers to ensure the depth and rigor of the analysis (Palmatier et al., 2018). Maintaining the quality of analysis should be assessing these four steps in the literature review, which are Design, Conduct, Abstraction \& Analysis, and Structuring \& Writing the Review. Those steps of integrative literature review are implemented in this study and described in the Table 2.

Table 2. The Research Process

Using Integrative Literature Review Approach

\begin{tabular}{|c|c|}
\hline $\begin{array}{c}\text { Research } \\
\text { Step }\end{array}$ & Detailed Research Process \\
\hline Design & $\begin{array}{l}\text { Reviewing the articles and papers regarding the literature review } \\
\text { methodology } \\
\text { - Contrasting and Comparing the previous publication which implementing } \\
\text { literature review of Marketing Research Trend } \\
\text { - Collecting the list of content published articles in the five preferred } \\
\text { journals (JOM, JAMS, JMR, JCR, MT). } \\
\text { - Assessing the validity of the publication by reviewing the H-Index, Citation } \\
\text { Index, and Categorisation based on index databases (SCOPUS \& WOS). }\end{array}$ \\
\hline Conduct & $\begin{array}{l}\text { Downloading the articles from all issue in the first semester } 2020 \text { and } 73 \\
\text { selected articles from } 2019 \text { as comparison. } \\
\text { - Categorizing the article, which dividing into literature review and } \\
\text { empirical research articles } \\
\text { - Designing the framework of analysis which focusing to the type of }\end{array}$ \\
\hline
\end{tabular}




\begin{tabular}{|c|c|}
\hline & $\begin{array}{l}\text { research, data collection method, and data analysis method. } \\
\text { Preparing working table (using Microsoft Excel) to categorized the code of } \\
\text { analysis. }\end{array}$ \\
\hline $\begin{array}{l}\text { Abstraction \& } \\
\text { Analysis }\end{array}$ & $\begin{array}{l}\text { - Reviewing each article, abstracting the code of analysis } \\
\text { - Categorizing the code in the Ms. Excel } \\
\text { - Finding pattern of the code analysis, focusing on methodological approach } \\
\text { of the researches } \\
\text { - Concluding the finding, capturing the methodological pattern to describe } \\
\text { the analysis report }\end{array}$ \\
\hline $\begin{array}{l}\text { Structuring \& } \\
\text { Writing }\end{array}$ & $\begin{array}{l}\text { - } \quad \text { Defining the report angle and perspective } \\
\text { - } \quad \text { Collecting supporting references and sources } \\
\text { - } \quad \text { Developing report framework } \\
\end{array}$ \\
\hline
\end{tabular}

Source: Based on Author's Own Research

Based on Table 2, the four steps of integrative literature review have been implemented in this study. First, in the research design, there are several literature review papers which have been referred in this study, such as literature review on sustainability research during 1958 - 2008 (Chabowski et al., 2011), systematic literature review on international business (Yang et al., 2006), literature review on implementing event study in marketing research (Sorescu et al., 2017), and the systematic literature review on research trend during 1990 - 2017 (Nicolas et al., 2020). Those references were being evaluated in the first step to enhance the knowledge and understanding regarding the literature review methodology in marketing studies.

Second step is conducting the data collection and testing its validity. In this study, data collection was done by downloading the article from its publisher sources with legal access from our university domain. Once papers were collected, review process was done manually by contrasting and comparing the article using the content analysis method.

Content analysis is an analysis which focusing to the meaning of textual data and interpreted the data using semantic approach by giving code and category (Huberman \& Miles, 2012). Therefore, for collecting and analysing the code and category, a table is designed using Microsoft Excel. All code and category are formatted to the Excel such as the type of sampling technique, data analysis method, and the research model and topic. All data were recorded to this table and it shows the pattern of the category to be next interpreted and concluded.

Third step is the abstracting and analysis the data. All data which have been collected in the table analysis are being reviewed and concluded to some specific category of analysis. Those categories are related to the research questions, which are focusing on the trend of research topic, trend on methodological approach in the sources, and the future research agenda which could be proposed based on this review.

Last step is writing the report of the study. Before writing down the findings, author was designed the report framework to give better understanding on an interesting article which preferred by the journal publishers. Some literature review papers were just directly describing the indexed papers in their study without any critical review on its analysis (Palmatier et al., 2018). A good literature review papers must avoid this mistake.

The transparent process in the literature review methodology should be expressed consistently by the researchers. This process is one of the method to ensure the validity and reliability of the data. Internal validity is one of the process which 
researchers implement the double check and triangulation of the data collected (Huberman \& Miles, 2012; Maxwell \& Reybold, 2015). Therefore, the internal validity is implemented in this study by rechecking the sources consistently. Face validity which concerning the connectivity and correlation between data analysis with the report writing was also applying to improve the quality of this article. There are four characteristic of a good literature review which are depth and rigor of the analysis, replicability by other researchers with the clear and transparent process, result and finding have better usability and contribution to the theory and practice, and last one is about the ease of writing format which easily understood by readers (Palmatier et al., 2018).

\section{Result and Findings}

This analysis is based on 146 articles which consisted of 73 articles published during first semester of 2020 and 73 selected articles from 2019 as comparison. Only literature review and empirical research articles were being analysed. Meanwhile, commentary, editorial note, book review, and other kind of publication in those journals were not included to the analysis. To ensure face validity, the title of all articles reviewed in this study are listed in the Table 3.

Table 3. List of Articles Reviewed in this Study

\begin{tabular}{|c|c|c|c|c|c|}
\hline \multicolumn{3}{|c|}{2020} & \multicolumn{3}{|c|}{2019} \\
\hline No & Title & Journal & No & Title & Journal \\
\hline 1 & $\begin{array}{l}\text { Categorical versus dimensional } \\
\text { thinking: improving anti-stigma } \\
\text { campaigns by matching health } \\
\text { message frames and implicit world } \\
\text { views }\end{array}$ & $\begin{array}{l}\text { Journal of } \\
\text { the Academy } \\
\text { of Marketing } \\
\text { Science }\end{array}$ & 74 & $\begin{array}{l}\text { Effects of channel members' } \\
\text { customer-centric structures on } \\
\text { supplier performance }\end{array}$ & $\begin{array}{l}\text { Journal of the } \\
\text { Academy of } \\
\text { Marketing } \\
\text { Science }\end{array}$ \\
\hline 2 & $\begin{array}{l}\text { Competitive spill-over elasticities } \\
\text { of electronic word of mouth: an } \\
\text { application to the soft drink } \\
\text { industry }\end{array}$ & $\begin{array}{l}\text { Journal of } \\
\text { the Academy } \\
\text { of Marketing } \\
\text { Science }\end{array}$ & 75 & $\begin{array}{l}\text { Focusing on others before you } \\
\text { shop: exposure to Facebook } \\
\text { promotes conventional product } \\
\text { configurations }\end{array}$ & $\begin{array}{l}\text { Journal of the } \\
\text { Academy of } \\
\text { Marketing } \\
\text { Science }\end{array}$ \\
\hline 3 & $\begin{array}{l}\text { Does the CMO's personality matter } \\
\text { for web traffic? Evidence from } \\
\text { technology-based new ventures }\end{array}$ & $\begin{array}{l}\text { Journal of } \\
\text { the Academy } \\
\text { of Marketing } \\
\text { Science }\end{array}$ & 76 & Customer engagement in service & $\begin{array}{l}\text { Journal of the } \\
\text { Academy of } \\
\text { Marketing } \\
\text { Science }\end{array}$ \\
\hline 4 & $\begin{array}{l}\text { Enhancing compliance among } \\
\text { channel members by modeling } \\
\text { reward events: matching } \\
\text { motivation and ability with model } \\
\text { selection }\end{array}$ & $\begin{array}{l}\text { Journal of } \\
\text { the Academy } \\
\text { of Marketing } \\
\text { Science }\end{array}$ & 77 & $\begin{array}{l}\text { Benefitting a few at the expense } \\
\text { of many? Exclusive promotions } \\
\text { and their impact on untargeted } \\
\text { customers }\end{array}$ & $\begin{array}{l}\text { Journal of the } \\
\text { Academy of } \\
\text { Marketing } \\
\text { Science }\end{array}$ \\
\hline 5 & $\begin{array}{l}\text { Price negotiating for services: } \\
\text { elucidating the ambivalent effects } \\
\text { on customers' negotiation } \\
\text { aspirations }\end{array}$ & $\begin{array}{l}\text { Journal of } \\
\text { the Academy } \\
\text { of Marketing } \\
\text { Science }\end{array}$ & 78 & $\begin{array}{l}\text { Does doing good lead to doing } \\
\text { better in emerging markets? } \\
\text { Stock market responses to the } \\
\text { SRI index announcements in } \\
\text { Brazil, China, and South Africa }\end{array}$ & $\begin{array}{l}\text { Journal of the } \\
\text { Academy of } \\
\text { Marketing } \\
\text { Science }\end{array}$ \\
\hline 6 & $\begin{array}{l}\text { Product set granularity and } \\
\text { consumer response to } \\
\text { recommendations }\end{array}$ & $\begin{array}{l}\text { Journal of } \\
\text { the Academy } \\
\text { of Marketing } \\
\text { Science }\end{array}$ & 79 & $\begin{array}{l}\text { Consideration ofethical attributes } \\
\text { along the consumer decision- } \\
\text { making journey }\end{array}$ & $\begin{array}{l}\text { Journal of the } \\
\text { Academy of } \\
\text { Marketing } \\
\text { Science }\end{array}$ \\
\hline
\end{tabular}




\begin{tabular}{|c|c|c|c|c|c|}
\hline 7 & $\begin{array}{l}\text { Seeing eye to eye: social } \\
\text { augmented reality and shared } \\
\text { decision making in the marketplace }\end{array}$ & $\begin{array}{l}\text { Journal of } \\
\text { the Academy } \\
\text { of Marketing } \\
\text { Science }\end{array}$ & 80 & $\begin{array}{l}\text { Cultural experiential goal pursuit, } \\
\text { cultural brand engagement, and } \\
\text { culturally authentic experiences: } \\
\text { sojourners in America }\end{array}$ & $\begin{array}{l}\text { Journal of the } \\
\text { Academy of } \\
\text { Marketing } \\
\text { Science }\end{array}$ \\
\hline 8 & $\begin{array}{l}\text { The give and take of cause-related } \\
\text { marketing: purchasing cause- } \\
\text { related products licenses consumer } \\
\text { indulgence }\end{array}$ & $\begin{array}{l}\text { Journal of } \\
\text { the Academy } \\
\text { of Marketing } \\
\text { Science }\end{array}$ & 81 & $\begin{array}{l}\text { Value creation in consumption } \\
\text { journeys: recursive reflexivity } \\
\text { and practice continuity }\end{array}$ & $\begin{array}{l}\text { Journal of the } \\
\text { Academy of } \\
\text { Marketing } \\
\text { Science }\end{array}$ \\
\hline 9 & $\begin{array}{l}\text { The impact of unprofitable } \\
\text { customer management strategies } \\
\text { on shareholder value }\end{array}$ & $\begin{array}{l}\text { Journal of } \\
\text { the Academy } \\
\text { of Marketing } \\
\text { Science }\end{array}$ & 82 & $\begin{array}{l}\text { Herding in the consumption and } \\
\text { purchase of digital goods and } \\
\text { moderators of the herding bias }\end{array}$ & $\begin{array}{l}\text { Journal of the } \\
\text { Academy of } \\
\text { Marketing } \\
\text { Science }\end{array}$ \\
\hline 10 & $\begin{array}{l}\text { When less is more: the downside of } \\
\text { customer knowledge sharing in } \\
\text { new product development teams }\end{array}$ & $\begin{array}{l}\text { Journal of } \\
\text { the Academy } \\
\text { of Marketing } \\
\text { Science }\end{array}$ & 83 & $\begin{array}{l}\text { Can attempts to delight } \\
\text { customers with surprise gains } \\
\text { boomerang? A test using low- } \\
\text { price guarantees }\end{array}$ & $\begin{array}{l}\text { Journal of the } \\
\text { Academy of } \\
\text { Marketing } \\
\text { Science }\end{array}$ \\
\hline 11 & $\begin{array}{l}\text { Accurately measuring willingness } \\
\text { to pay for consumer goods: a meta- } \\
\text { analysis of the hypothetical bias }\end{array}$ & $\begin{array}{l}\text { Journal of } \\
\text { the Academy } \\
\text { of Marketing } \\
\text { Science }\end{array}$ & 84 & $\begin{array}{l}\text { Employee-level open innovation } \\
\text { in emerging markets: linking } \\
\text { internal, external, and } \\
\text { managerial resources }\end{array}$ & $\begin{array}{l}\text { Journal of the } \\
\text { Academy of } \\
\text { Marketing } \\
\text { Science }\end{array}$ \\
\hline 12 & $\begin{array}{l}\text { Cross-price elasticities and their } \\
\text { determinants: a meta-analysis and } \\
\text { new empirical generalizations }\end{array}$ & $\begin{array}{l}\text { Journal of } \\
\text { the Academy } \\
\text { of Marketing } \\
\text { Science }\end{array}$ & 85 & $\begin{array}{l}\text { Employee-level open innovation } \\
\text { in emerging markets: linking } \\
\text { internal, external, and } \\
\text { managerial resources }\end{array}$ & $\begin{array}{l}\text { Journal of the } \\
\text { Academy of } \\
\text { Marketing } \\
\text { Science }\end{array}$ \\
\hline 13 & $\begin{array}{l}\text { Company Worth Keeping: Personal } \\
\text { Control and Preferences for Brand } \\
\text { Leaders }\end{array}$ & $\begin{array}{l}\text { Journal of } \\
\text { Consumer } \\
\text { Research }\end{array}$ & 86 & $\begin{array}{l}\text { Innovation for and from } \\
\text { emerging countries: a closer look } \\
\text { at the antecedents of trickle- } \\
\text { down and reverse innovation }\end{array}$ & $\begin{array}{l}\text { Journal of the } \\
\text { Academy of } \\
\text { Marketing } \\
\text { Science }\end{array}$ \\
\hline 14 & $\begin{array}{l}\text { Contraction with Unpacking: When } \\
\text { Unpacking Leads to Lower Calorie } \\
\text { Budgets }\end{array}$ & $\begin{array}{l}\text { Journal of } \\
\text { Consumer } \\
\text { Research }\end{array}$ & 87 & $\begin{array}{l}\text { Effective customer journey } \\
\text { design: consumers' conception, } \\
\text { measurement, and consequences }\end{array}$ & $\begin{array}{l}\text { Journal of the } \\
\text { Academy of } \\
\text { Marketing } \\
\text { Science }\end{array}$ \\
\hline 15 & $\begin{array}{l}\text { I Am, Therefore I Buy: } \\
\text { Low Self-Esteem and the Pursuit of } \\
\text { Self-Verifying Consumption }\end{array}$ & $\begin{array}{l}\text { Journal of } \\
\text { Consumer } \\
\text { Research }\end{array}$ & 88 & $\begin{array}{l}\text { The effects of loyalty program } \\
\text { introduction and design on short- } \\
\text { and long-term sales and gross } \\
\text { profits }\end{array}$ & $\begin{array}{l}\text { Journal of the } \\
\text { Academy of } \\
\text { Marketing } \\
\text { Science }\end{array}$ \\
\hline 16 & $\begin{array}{l}\text { Probable Cause: The Influence of } \\
\text { Prior Probabilities on Forecasts } \\
\text { and Perceptions of Magnitude }\end{array}$ & $\begin{array}{l}\text { Journal of } \\
\text { Consumer } \\
\text { Research }\end{array}$ & 89 & $\begin{array}{l}\text { Exploring the link between } \\
\text { payment schemes and customer } \\
\text { fraud: a mental accounting } \\
\text { perspective }\end{array}$ & $\begin{array}{l}\text { Journal of the } \\
\text { Academy of } \\
\text { Marketing } \\
\text { Science }\end{array}$ \\
\hline 17 & $\begin{array}{l}\text { Profiling Victims of Investment } \\
\text { Fraud: Mindsets and Risky } \\
\text { Behaviors }\end{array}$ & $\begin{array}{l}\text { Journal of } \\
\text { Consumer } \\
\text { Research }\end{array}$ & 90 & $\begin{array}{l}\text { Driving growth of M-wallets in } \\
\text { emerging markets: a retailer's } \\
\text { perspective }\end{array}$ & $\begin{array}{l}\text { Journal of the } \\
\text { Academy of } \\
\text { Marketing } \\
\text { Science }\end{array}$ \\
\hline 18 & Smiling Signals Intrinsic Motivation & $\begin{array}{l}\text { Journal of } \\
\text { Consumer } \\
\text { Research }\end{array}$ & 91 & $\begin{array}{l}\text { Identity Threats, Compensatory } \\
\text { Consumption, and Working } \\
\text { Memory Capacity: How Feeling } \\
\text { Threatened Leads to Heightened } \\
\text { Evaluations of Identity-Relevant } \\
\text { Products }\end{array}$ & $\begin{array}{l}\text { Journal of } \\
\text { Consumer } \\
\text { Research }\end{array}$ \\
\hline
\end{tabular}




\begin{tabular}{|c|c|c|c|c|c|}
\hline 19 & $\begin{array}{l}\text { The Influence of Product } \\
\text { Anthropomorphism on } \\
\text { Comparative Judgment }\end{array}$ & $\begin{array}{l}\text { Journal of } \\
\text { Consumer } \\
\text { Research }\end{array}$ & 92 & $\begin{array}{l}\text { Deception Memory: When Will } \\
\text { Consumers Remember Their } \\
\text { Lies? }\end{array}$ & $\begin{array}{l}\text { Journal of } \\
\text { Consumer } \\
\text { Research }\end{array}$ \\
\hline 20 & $\begin{array}{l}\text { The Meaning of Distraction: How } \\
\text { Metacognitive Inferences from } \\
\text { Distraction during Multitasking } \\
\text { Affect Brand Evaluations }\end{array}$ & $\begin{array}{l}\text { Journal of } \\
\text { Consumer } \\
\text { Research }\end{array}$ & 93 & $\begin{array}{l}\text { It's the End of the Competition: } \\
\text { When Social Comparison Is Not } \\
\text { Always Motivating for Goal } \\
\text { Achievement }\end{array}$ & $\begin{array}{l}\text { Journal of } \\
\text { Consumer } \\
\text { Research }\end{array}$ \\
\hline 21 & $\begin{array}{l}\text { The Uncertain Self: } \\
\text { How Self-Concept Structure Affects } \\
\text { Subscription Choice }\end{array}$ & $\begin{array}{l}\text { Journal of } \\
\text { Consumer } \\
\text { Research }\end{array}$ & 94 & $\begin{array}{l}\text { Nonconscious Nudges: } \\
\text { Encouraging Sustained Goal } \\
\text { Pursuit }\end{array}$ & $\begin{array}{l}\text { Journal of } \\
\text { Consumer } \\
\text { Research }\end{array}$ \\
\hline 22 & $\begin{array}{l}\text { People Rely Less on Consumer } \\
\text { Reviews for Experiential Than } \\
\text { Material Purchases }\end{array}$ & $\begin{array}{l}\text { Journal of } \\
\text { Consumer } \\
\text { Research }\end{array}$ & 95 & $\begin{array}{l}\text { The Bad Can Be Good: When } \\
\text { Benign and Malicious Envy } \\
\text { Motivate Goal Pursuit }\end{array}$ & $\begin{array}{l}\text { Journal of } \\
\text { Consumer } \\
\text { Research }\end{array}$ \\
\hline 23 & $\begin{array}{l}\text { Saving Your Self: How Identity } \\
\text { Relevance Influences Product } \\
\text { Usage }\end{array}$ & $\begin{array}{l}\text { Journal of } \\
\text { Consumer } \\
\text { Research }\end{array}$ & 96 & $\begin{array}{l}\text { What Happens in Vegas Stays on } \\
\text { TripAdvisor? A Theory and } \\
\text { Technique to Understand } \\
\text { Narrativity in Consumer Reviews }\end{array}$ & $\begin{array}{l}\text { Journal of } \\
\text { Consumer } \\
\text { Research }\end{array}$ \\
\hline 24 & $\begin{array}{l}\text { The Impact of Resource Scarcity on } \\
\text { Price-Quality Judgments }\end{array}$ & $\begin{array}{l}\text { Journal of } \\
\text { Consumer } \\
\text { Research }\end{array}$ & 97 & $\begin{array}{l}\text { Unexpected-Framing Effect: } \\
\text { Impact of Framing a Product } \\
\text { Benefit as Unexpected on } \\
\text { Product Desire }\end{array}$ & $\begin{array}{l}\text { Journal of } \\
\text { Consumer } \\
\text { Research }\end{array}$ \\
\hline 25 & $\begin{array}{l}\text { The Impostor Syndrome from } \\
\text { Luxury Consumption }\end{array}$ & $\begin{array}{l}\text { Journal of } \\
\text { Consumer } \\
\text { Research }\end{array}$ & 98 & $\begin{array}{l}\text { The Devil You Know: Self- } \\
\text { Esteem and Switching Responses } \\
\text { to Poor Service }\end{array}$ & $\begin{array}{l}\text { Journal of } \\
\text { Consumer } \\
\text { Research }\end{array}$ \\
\hline 26 & $\begin{array}{l}\text { The Many-Faced Consumer: } \\
\text { Consumption Consequences of } \\
\text { Balancing Multiple Identities }\end{array}$ & $\begin{array}{l}\text { Journal of } \\
\text { Consumer } \\
\text { Research }\end{array}$ & 99 & $\begin{array}{l}\text { Restraint that Blinds: Attention } \\
\text { Narrowing and Consumers' } \\
\text { Response to Numerosity in Self- } \\
\text { Control Decisions }\end{array}$ & $\begin{array}{l}\text { Journal of } \\
\text { Consumer } \\
\text { Research }\end{array}$ \\
\hline 27 & $\begin{array}{l}\text { The Secrecy Effect: Secret } \\
\text { Consumption Increases Women's } \\
\text { Product Evaluations and Choice }\end{array}$ & $\begin{array}{l}\text { Journal of } \\
\text { Consumer } \\
\text { Research }\end{array}$ & 100 & $\begin{array}{l}\text { The Influence of Health } \\
\text { Motivation and Calorie-Ending } \\
\text { on Preferences for Indulgent } \\
\text { Foods }\end{array}$ & $\begin{array}{l}\text { Journal of } \\
\text { Consumer } \\
\text { Research }\end{array}$ \\
\hline 28 & $\begin{array}{l}\text { A Theories-in-Use Approach to } \\
\text { Building Marketing Theory }\end{array}$ & $\begin{array}{l}\text { Journal of } \\
\text { Marketing }\end{array}$ & 101 & $\begin{array}{l}\text { Consumer Movements and Value } \\
\text { Regimes: Fighting Food Waste in } \\
\text { Germany by Building Alternative } \\
\text { Object Pathways }\end{array}$ & $\begin{array}{l}\text { Journal of } \\
\text { Consumer } \\
\text { Research }\end{array}$ \\
\hline 29 & $\begin{array}{l}\text { Dynamic Governance Matching in } \\
\text { Solution Development }\end{array}$ & $\begin{array}{l}\text { Journal of } \\
\text { Marketing }\end{array}$ & 102 & $\begin{array}{l}\text { Wine for the Table: Self- } \\
\text { Construal, Group Size, and Choice } \\
\text { for Self and Others }\end{array}$ & $\begin{array}{l}\text { Journal of } \\
\text { Consumer } \\
\text { Research }\end{array}$ \\
\hline 30 & $\begin{array}{l}\text { Featuring Mistakes: The Persuasive } \\
\text { Impact of Purchase Mistakes in } \\
\text { Online Reviews }\end{array}$ & $\begin{array}{l}\text { Journal of } \\
\text { Marketing }\end{array}$ & 103 & $\begin{array}{l}\text { Differential Construal of Exercise } \\
\text { versus Diet and Implications for } \\
\text { Weight Control }\end{array}$ & $\begin{array}{l}\text { Journal of } \\
\text { Consumer } \\
\text { Research }\end{array}$ \\
\hline 31 & $\begin{array}{l}\text { Pleasant Ambient Scents: A Meta- } \\
\text { Analysis of Customer Responses } \\
\text { and Situational Contingencies }\end{array}$ & $\begin{array}{l}\text { Journal of } \\
\text { Marketing }\end{array}$ & 104 & $\begin{array}{l}\text { The Body as (Another) Place: } \\
\text { Producing Embodied } \\
\text { Heterotopias through Tattooing }\end{array}$ & $\begin{array}{l}\text { Journal of } \\
\text { Consumer } \\
\text { Research }\end{array}$ \\
\hline 32 & $\begin{array}{l}\text { Understanding the Impact of } \\
\text { Relationship Disruptions }\end{array}$ & $\begin{array}{l}\text { Journal of } \\
\text { Marketing }\end{array}$ & 105 & $\begin{array}{l}\text { The Best Laid Plans: Why New } \\
\text { Parents Fail to Habituate } \\
\text { Practices }\end{array}$ & $\begin{array}{l}\text { Journal of } \\
\text { Consumer } \\
\text { Research }\end{array}$ \\
\hline 33 & $\begin{array}{l}\text { Uniting the Tribes: Using Text for } \\
\text { Marketing Insight }\end{array}$ & $\begin{array}{l}\text { Journal of } \\
\text { Marketing }\end{array}$ & 106 & $\begin{array}{l}\text { Extending the Boundaries of } \\
\text { Sensory Marketing and } \\
\text { Examining the Sixth Sensory } \\
\text { System: Effects of Vestibular } \\
\text { Sensations for Sitting versus } \\
\text { Standing Postures on Food Taste }\end{array}$ & $\begin{array}{l}\text { Journal of } \\
\text { Consumer } \\
\text { Research }\end{array}$ \\
\hline
\end{tabular}




\begin{tabular}{|c|c|c|c|c|c|}
\hline 34 & $\begin{array}{l}\text { Who Receives Credit or Blame? The } \\
\text { Effects of Made-to-Order } \\
\text { Production on Responses to } \\
\text { Unethical and Ethical Company } \\
\text { Production Practices }\end{array}$ & $\begin{array}{l}\text { Journal of } \\
\text { Marketing }\end{array}$ & 107 & $\begin{array}{l}\text { Charities Can Increase the } \\
\text { Effectiveness of Donation } \\
\text { Appeals by Using a Morally } \\
\text { Congruent Positive Emotion }\end{array}$ & $\begin{array}{l}\text { Journal of } \\
\text { Consumer } \\
\text { Research }\end{array}$ \\
\hline 35 & $\begin{array}{l}\text { Business-to-Business E- } \\
\text { Negotiations and Influence Tactics }\end{array}$ & $\begin{array}{l}\text { Journal of } \\
\text { Marketing }\end{array}$ & 108 & $\begin{array}{l}\text { A market approach to social } \\
\text { value co-creation: Findings and } \\
\text { implications from "Mageires" the } \\
\text { social restaurant }\end{array}$ & $\begin{array}{l}\text { Journal of } \\
\text { Marketing }\end{array}$ \\
\hline 36 & $\begin{array}{l}\text { Evaluating the Effectiveness of } \\
\text { Retailer-Themed Super Saver } \\
\text { Events }\end{array}$ & $\begin{array}{l}\text { Journal of } \\
\text { Marketing }\end{array}$ & 109 & $\begin{array}{l}\text { Evaluating festival attributes } \\
\text { adopting S-D logic: The } \\
\text { mediating role of visitor } \\
\text { experience and visitor } \\
\text { satisfaction }\end{array}$ & $\begin{array}{l}\text { Journal of } \\
\text { Marketing }\end{array}$ \\
\hline 37 & $\begin{array}{l}\text { Improvised Marketing } \\
\text { Interventions in Social Media }\end{array}$ & $\begin{array}{l}\text { Journal of } \\
\text { Marketing }\end{array}$ & 110 & $\begin{array}{l}\text { An Integrated Power and } \\
\text { Efficiency Model of Contractual } \\
\text { Channel Governance: Theory and } \\
\text { Empirical Evidence }\end{array}$ & $\begin{array}{l}\text { Journal of } \\
\text { Marketing }\end{array}$ \\
\hline 38 & $\begin{array}{l}\text { Marketing-Mix Response Across } \\
\text { Retail Formats: The Role of } \\
\text { Shopping } \\
\text { Trip Types }\end{array}$ & $\begin{array}{l}\text { Journal of } \\
\text { Marketing }\end{array}$ & 111 & $\begin{array}{l}\text { Does It Pay to Be Real? } \\
\text { Understanding Authenticity in TV } \\
\text { Advertising }\end{array}$ & $\begin{array}{l}\text { Journal of } \\
\text { Marketing }\end{array}$ \\
\hline 39 & $\begin{array}{l}\text { When and Why Saying "Thank You" } \\
\text { Is Better Than Saying "Sorry" in } \\
\text { Redressing Service Failures: The } \\
\text { Role of Self-Esteem }\end{array}$ & $\begin{array}{l}\text { Journal of } \\
\text { Marketing }\end{array}$ & 112 & $\begin{array}{l}\text { Creating Effective Online } \\
\text { Customer Experiences }\end{array}$ & $\begin{array}{l}\text { Journal of } \\
\text { Marketing }\end{array}$ \\
\hline 40 & $\begin{array}{l}\text { Branding Cultural Products in } \\
\text { International Markets: A Study of } \\
\text { Hollywood Movies } \\
\text { in China }\end{array}$ & $\begin{array}{l}\text { Journal of } \\
\text { Marketing }\end{array}$ & 113 & $\begin{array}{l}\text { Does a Customer on the Board of } \\
\text { Directors Affect Business-to- } \\
\text { Business Firm Performance? }\end{array}$ & $\begin{array}{l}\text { Journal of } \\
\text { Marketing }\end{array}$ \\
\hline 41 & $\begin{array}{l}\text { Full Disclosure: How Smartphones } \\
\text { Enhance Consumer Self-Disclosure }\end{array}$ & $\begin{array}{l}\text { Journal of } \\
\text { Marketing }\end{array}$ & 114 & Brand Coolness & $\begin{array}{l}\text { Journal of } \\
\text { Marketing }\end{array}$ \\
\hline 42 & $\begin{array}{l}\text { Help Me Help You! Employing the } \\
\text { Marketing Mix to Alleviate } \\
\text { Experiences of Donor Sacrifice }\end{array}$ & $\begin{array}{l}\text { Journal of } \\
\text { Marketing }\end{array}$ & 115 & $\begin{array}{l}\text { Can Advertising Investments } \\
\text { Counter the Negative Impact of } \\
\text { Shareholder Complaints on Firm } \\
\text { Value? }\end{array}$ & $\begin{array}{l}\text { Journal of } \\
\text { Marketing }\end{array}$ \\
\hline 43 & $\begin{array}{l}\text { Highlighting Effort Versus Talent } \\
\text { in Service Employee Performance: } \\
\text { Customer Attributions and } \\
\text { Responses }\end{array}$ & $\begin{array}{l}\text { Journal of } \\
\text { Marketing }\end{array}$ & 116 & $\begin{array}{l}\text { Cueing Morality: The Effect of } \\
\text { High-Pitched Music on Healthy } \\
\text { Choice }\end{array}$ & $\begin{array}{l}\text { Journal of } \\
\text { Marketing }\end{array}$ \\
\hline 44 & $\begin{array}{l}\text { Improving Cancer Outreach } \\
\text { Effectiveness Through Targeting } \\
\text { and Economic Assessments: } \\
\text { Insights from a Randomized Field } \\
\text { Experiment }\end{array}$ & $\begin{array}{l}\text { Journal of } \\
\text { Marketing }\end{array}$ & 117 & $\begin{array}{l}\text { Driving Brand Engagement } \\
\text { Through Online Social } \\
\text { Influencers: An Empirical } \\
\text { Investigation of Sponsored } \\
\text { Blogging Campaigns }\end{array}$ & $\begin{array}{l}\text { Journal of } \\
\text { Marketing }\end{array}$ \\
\hline 45 & $\begin{array}{l}\text { The Commercial Consequences of } \\
\text { Collective Layoffs: Close the Plant, } \\
\text { Lose the Brand? }\end{array}$ & $\begin{array}{l}\text { Journal of } \\
\text { Marketing }\end{array}$ & 118 & $\begin{array}{l}\text { Market Intelligence } \\
\text { Dissemination Practices }\end{array}$ & $\begin{array}{l}\text { Journal of } \\
\text { Marketing }\end{array}$ \\
\hline 46 & $\begin{array}{l}\text { When Does Corporate Social } \\
\text { Irresponsibility Become News? } \\
\text { Evidence from More Than 1,000 } \\
\text { Brand Transgressions Across Five } \\
\text { Countries }\end{array}$ & $\begin{array}{l}\text { Journal of } \\
\text { Marketing }\end{array}$ & 119 & $\begin{array}{l}\text { Gift Purchases as Catalysts for } \\
\text { Strengthening Customer-Brand } \\
\text { Relationships }\end{array}$ & $\begin{array}{l}\text { Journal of } \\
\text { Marketing }\end{array}$ \\
\hline
\end{tabular}




\begin{tabular}{|c|c|c|c|c|c|}
\hline 47 & $\begin{array}{l}\text { A Multiattribute Benefits-Based } \\
\text { Choice Model with Multiple } \\
\text { Mediators: } \\
\text { New Insights for Positioning }\end{array}$ & $\begin{array}{l}\text { Journal of } \\
\text { Marketing } \\
\text { Research }\end{array}$ & 120 & $\begin{array}{l}\text { In Mobile We Trust: The Effects } \\
\text { of Mobile Versus Nonmobile } \\
\text { Reviews on Consumer Purchase } \\
\text { Intentions }\end{array}$ & $\begin{array}{l}\text { Journal of } \\
\text { Marketing } \\
\text { Research }\end{array}$ \\
\hline 48 & $\begin{array}{l}\text { Is a Picture Worth a Thousand } \\
\text { Words? An Empirical Study of } \\
\text { Image Content and Social Media } \\
\text { Engagement }\end{array}$ & $\begin{array}{l}\text { Journal of } \\
\text { Marketing } \\
\text { Research }\end{array}$ & 121 & $\begin{array}{l}\text { Let the Logo Do the Talking: The } \\
\text { Influence of Logo Descriptiveness } \\
\text { on Brand Equity }\end{array}$ & $\begin{array}{l}\text { Journal of } \\
\text { Marketing } \\
\text { Research }\end{array}$ \\
\hline 49 & $\begin{array}{l}\text { Mindful Matching: Ordinal Versus } \\
\text { Nominal Attributes }\end{array}$ & $\begin{array}{l}\text { Journal of } \\
\text { Marketing } \\
\text { Research }\end{array}$ & 122 & $\begin{array}{l}\text { Product Launches with New } \\
\text { Attributes: A Hybrid Conjoint- } \\
\text { Consumer Panel Technique for } \\
\text { Estimating Demand }\end{array}$ & $\begin{array}{l}\text { Journal of } \\
\text { Marketing } \\
\text { Research }\end{array}$ \\
\hline 50 & $\begin{array}{l}\text { Modeling Dynamic Heterogeneity } \\
\text { Using Gaussian Processes }\end{array}$ & $\begin{array}{l}\text { Journal of } \\
\text { Marketing } \\
\text { Research }\end{array}$ & 123 & $\begin{array}{l}\text { The Value of Rapid Delivery in } \\
\text { Omnichannel Retailing }\end{array}$ & $\begin{array}{l}\text { Journal of } \\
\text { Marketing } \\
\text { Research }\end{array}$ \\
\hline 51 & $\begin{array}{l}\text { Native Advertising in Online News: } \\
\text { Trade-Offs Among Clicks, Brand } \\
\text { Recognition, } \\
\text { and Website Trustworthiness }\end{array}$ & $\begin{array}{l}\text { Journal of } \\
\text { Marketing } \\
\text { Research }\end{array}$ & 124 & $\begin{array}{l}\text { When "More" Seems Like Less: } \\
\text { Differential Price Framing } \\
\text { Increases the Choice Share of } \\
\text { Higher-Priced Options }\end{array}$ & $\begin{array}{l}\text { Journal of } \\
\text { Marketing } \\
\text { Research }\end{array}$ \\
\hline 52 & $\begin{array}{l}\text { On the Other Hand...: Enhancing } \\
\text { Promotional Effectiveness with } \\
\text { Haptic Cues }\end{array}$ & $\begin{array}{l}\text { Journal of } \\
\text { Marketing } \\
\text { Research }\end{array}$ & 125 & $\begin{array}{l}\text { When Salespeople Manage } \\
\text { Customer Relationships: } \\
\text { Multidimensional Incentives and } \\
\text { Private Information }\end{array}$ & $\begin{array}{l}\text { Journal of } \\
\text { Marketing } \\
\text { Research }\end{array}$ \\
\hline 53 & Price Promotions Cause Impatience & $\begin{array}{l}\text { Journal of } \\
\text { Marketing } \\
\text { Research }\end{array}$ & 126 & $\begin{array}{l}\text { Media Coverage of Climate } \\
\text { Change and Sustainable Product } \\
\text { Consumption: Evidence from the } \\
\text { Hybrid Vehicle Market }\end{array}$ & $\begin{array}{l}\text { Journal of } \\
\text { Marketing } \\
\text { Research }\end{array}$ \\
\hline 54 & $\begin{array}{l}\text { The Differential Effect of Local- } \\
\text { Global Identity Among Males and } \\
\text { Females: The Case of Price } \\
\text { Sensitivity }\end{array}$ & $\begin{array}{l}\text { Journal of } \\
\text { Marketing } \\
\text { Research }\end{array}$ & 127 & $\begin{array}{l}\text { Personalizing the Customization } \\
\text { Experience: A Matching Theory } \\
\text { of Mass Customization Interfaces } \\
\text { and Cultural Information } \\
\text { Processing }\end{array}$ & $\begin{array}{l}\text { Journal of } \\
\text { Marketing } \\
\text { Research }\end{array}$ \\
\hline 55 & $\begin{array}{l}\text { Transparency of Behavior-Based } \\
\text { Pricing }\end{array}$ & $\begin{array}{l}\text { Journal of } \\
\text { Marketing } \\
\text { Research }\end{array}$ & 128 & $\begin{array}{l}\text { The Impact of Increasing Search } \\
\text { Frictions on Online Shopping } \\
\text { Behavior: Evidence from a Field } \\
\text { Experiment }\end{array}$ & $\begin{array}{l}\text { Journal of } \\
\text { Marketing } \\
\text { Research }\end{array}$ \\
\hline 56 & $\begin{array}{l}\text { Why Prosocial Referral Incentives } \\
\text { Work: The Interplay of } \\
\text { Reputational Benefits and Action } \\
\text { Costs }\end{array}$ & $\begin{array}{l}\text { Journal of } \\
\text { Marketing } \\
\text { Research }\end{array}$ & 129 & $\begin{array}{l}\text { The Surprising Breadth of } \\
\text { Harbingers of Failure }\end{array}$ & $\begin{array}{l}\text { Journal of } \\
\text { Marketing } \\
\text { Research }\end{array}$ \\
\hline 57 & $\begin{array}{l}\text { Communicating Brands in } \\
\text { Television Advertising }\end{array}$ & $\begin{array}{l}\text { Journal of } \\
\text { Marketing } \\
\text { Research }\end{array}$ & 130 & $\begin{array}{l}\text { When Does Customer } \\
\text { Participation Matter? An } \\
\text { Empirical Investigation of the } \\
\text { Role of Customer Empowerment } \\
\text { in the Customer Participation- } \\
\text { Performance Link }\end{array}$ & $\begin{array}{l}\text { Journal of } \\
\text { Marketing } \\
\text { Research }\end{array}$ \\
\hline 58 & $\begin{array}{l}\text { Designed to S(m)ell: When Scented } \\
\text { Advertising Induces Proximity } \\
\text { and Enhances Appeal }\end{array}$ & $\begin{array}{l}\text { Journal of } \\
\text { Marketing } \\
\text { Research }\end{array}$ & 131 & $\begin{array}{l}\text { When Words Sweat: Identifying } \\
\text { Signals for Loan Default in the } \\
\text { Text of Loan Applications }\end{array}$ & $\begin{array}{l}\text { Journal of } \\
\text { Marketing } \\
\text { Research }\end{array}$ \\
\hline 59 & $\begin{array}{l}\text { Inaction Traps in Consumer } \\
\text { Response to Product Malfunctions }\end{array}$ & $\begin{array}{l}\text { Journal of } \\
\text { Marketing } \\
\text { Research }\end{array}$ & 132 & $\begin{array}{l}\text { Brand Name Types and } \\
\text { Consumer Demand: Evidence } \\
\text { from China's Automobile Market }\end{array}$ & $\begin{array}{l}\text { Journal of } \\
\text { Marketing } \\
\text { Research }\end{array}$ \\
\hline 60 & $\begin{array}{l}\text { Leveraging Brand Equity for } \\
\text { Effective Visual Product Design }\end{array}$ & $\begin{array}{l}\text { Journal of } \\
\text { Marketing } \\
\text { Research }\end{array}$ & 133 & $\begin{array}{l}\text { Branded Apps and Their Impact } \\
\text { on Firm Value: A Design } \\
\text { Perspective }\end{array}$ & $\begin{array}{l}\text { Journal of } \\
\text { Marketing } \\
\text { Research }\end{array}$ \\
\hline
\end{tabular}




\begin{tabular}{|c|c|c|c|c|c|}
\hline 61 & $\begin{array}{l}\text { Marketplace Donations: The Role of } \\
\text { Moral Identity Discrepancy and } \\
\text { Gender }\end{array}$ & $\begin{array}{l}\text { Journal of } \\
\text { Marketing } \\
\text { Research }\end{array}$ & 134 & $\begin{array}{l}\text { Capital Market Returns to New } \\
\text { Product Development Success: } \\
\text { Informational Effects on Product } \\
\text { Market Advertising }\end{array}$ & $\begin{array}{l}\text { Journal of } \\
\text { Marketing } \\
\text { Research }\end{array}$ \\
\hline 62 & $\begin{array}{l}\text { Multiperiod Contracting and } \\
\text { Salesperson Effort Profiles: The } \\
\text { Optimality of "Hockey Stick," } \\
\text { "Giving Up," and "Resting on } \\
\text { Laurels" }\end{array}$ & $\begin{array}{l}\text { Journal of } \\
\text { Marketing } \\
\text { Research }\end{array}$ & 135 & $\begin{array}{l}\text { Extracting Features of } \\
\text { Entertainment Products: A } \\
\text { Guided Latent Dirichlet } \\
\text { Allocation Approach Informed } \\
\text { by the Psychology of Media } \\
\text { Consumption }\end{array}$ & $\begin{array}{l}\text { Journal of } \\
\text { Marketing } \\
\text { Research }\end{array}$ \\
\hline 63 & $\begin{array}{l}\text { Nonprofit Versus For-Profit Health } \\
\text { Care Competition: How Service Mix } \\
\text { Makes Nonprofit Hospitals More } \\
\text { Profitable }\end{array}$ & $\begin{array}{l}\text { Journal of } \\
\text { Marketing } \\
\text { Research }\end{array}$ & 136 & $\begin{array}{l}\text { Falling Back on Numbers: When } \\
\text { Preference for Numerical } \\
\text { Product Information Increases } \\
\text { after a Personal Control Threat }\end{array}$ & $\begin{array}{l}\text { Journal of } \\
\text { Marketing } \\
\text { Research }\end{array}$ \\
\hline 64 & $\begin{array}{l}\text { Service Providers' Decision to Use } \\
\text { Ethics Committees and } \\
\text { Consultation in Complex Services }\end{array}$ & $\begin{array}{l}\text { Journal of } \\
\text { Marketing } \\
\text { Research }\end{array}$ & 137 & $\begin{array}{l}\text { Managing advertising agency } \\
\text { client partnerships for value co- } \\
\text { creation: Characteristics, } \\
\text { categories, and challenges }\end{array}$ & $\begin{array}{l}\text { Marketing } \\
\text { Theory }\end{array}$ \\
\hline 65 & $\begin{array}{l}\text { The Enhancing Versus Backfiring } \\
\text { Effects of Positive Emotion in } \\
\text { Consumer Reviews }\end{array}$ & $\begin{array}{l}\text { Journal of } \\
\text { Marketing } \\
\text { Research }\end{array}$ & 138 & $\begin{array}{l}\text { Value proposition as a } \\
\text { framework for value cocreation } \\
\text { in crowdfunding ecosystems }\end{array}$ & $\begin{array}{l}\text { Marketing } \\
\text { Theory }\end{array}$ \\
\hline 66 & $\begin{array}{l}\text { The Strength of Weak-Tie } \\
\text { Consensus Language }\end{array}$ & $\begin{array}{l}\text { Journal of } \\
\text { Consumer } \\
\text { Research }\end{array}$ & 139 & $\begin{array}{l}\text { A market approach to social } \\
\text { value co-creation: Findings and } \\
\text { implications from "Mageires" the } \\
\text { social restaurant }\end{array}$ & $\begin{array}{l}\text { Marketing } \\
\text { Theory }\end{array}$ \\
\hline 67 & The politics of consumer data & $\begin{array}{l}\text { Marketing } \\
\text { Theory }\end{array}$ & 140 & $\begin{array}{l}\text { Conceptualizing resource } \\
\text { integration as an embedded } \\
\text { process: Matching, resourcing } \\
\text { and valuing }\end{array}$ & $\begin{array}{l}\text { Marketing } \\
\text { Theory }\end{array}$ \\
\hline 68 & $\begin{array}{l}\text { Collective reflexivity in social } \\
\text { marketing through ethnographic } \\
\text { film-making: The Yolngu story of } \\
\text { tobacco in Yirrkala, Australia }\end{array}$ & $\begin{array}{l}\text { Marketing } \\
\text { Theory }\end{array}$ & 141 & $\begin{array}{l}\text { Evaluating festival attributes } \\
\text { adopting S-D logic: The } \\
\text { mediating role of visitor } \\
\text { experience and visitor } \\
\text { satisfaction }\end{array}$ & $\begin{array}{l}\text { Marketing } \\
\text { Theory }\end{array}$ \\
\hline 69 & $\begin{array}{l}\text { New dynamics of social status and } \\
\text { distinction }\end{array}$ & $\begin{array}{l}\text { Marketing } \\
\text { Theory }\end{array}$ & 142 & $\begin{array}{l}\text { Know your customer: Client } \\
\text { captivation and the epistemics of } \\
\text { market research }\end{array}$ & $\begin{array}{l}\text { Marketing } \\
\text { Theory }\end{array}$ \\
\hline 70 & $\begin{array}{l}\text { Portable technology and multi- } \\
\text { domain energy practices }\end{array}$ & $\begin{array}{l}\text { Marketing } \\
\text { Theory }\end{array}$ & 143 & $\begin{array}{l}\text { Lifeway alibis: The biographical } \\
\text { bases for unruly bricolage }\end{array}$ & $\begin{array}{l}\text { Marketing } \\
\text { Theory }\end{array}$ \\
\hline 71 & $\begin{array}{l}\text { Seduced by "fakes": Producing the } \\
\text { excessive interplay of } \\
\text { authentic/counterfeit from a } \\
\text { Baudrillardian perspective }\end{array}$ & $\begin{array}{l}\text { Marketing } \\
\text { Theory }\end{array}$ & 144 & $\begin{array}{l}\text { 'I once wore an angry bird T-shirt } \\
\text { and went to read Qur'an': } \\
\text { Asymmetrical institutional } \\
\text { complexity and emerging } \\
\text { consumption practices in } \\
\text { Pakistan }\end{array}$ & $\begin{array}{l}\text { Marketing } \\
\text { Theory }\end{array}$ \\
\hline 72 & $\begin{array}{l}\text { Soldiers and superheroes needed! } \\
\text { Masculine archetypes and } \\
\text { constrained bodily } \\
\text { commodification in the sperm } \\
\text { donation market }\end{array}$ & $\begin{array}{l}\text { Marketing } \\
\text { Theory }\end{array}$ & 145 & $\begin{array}{l}\text { 'Made to run': Biopolitical } \\
\text { marketing and the making of the } \\
\text { self-quantified runner }\end{array}$ & $\begin{array}{l}\text { Marketing } \\
\text { Theory }\end{array}$ \\
\hline 73 & $\begin{array}{l}\text { You need 'help for the journey': } \\
\text { Freedom and regulation in } \\
\text { a 'market-friendly' megachurch }\end{array}$ & $\begin{array}{l}\text { Marketing } \\
\text { Theory }\end{array}$ & 146 & $\begin{array}{l}\text { Managing collective } \\
\text { effervescence: 'Zomsumption' } \\
\text { and postemotional fandom }\end{array}$ & $\begin{array}{l}\text { Marketing } \\
\text { Theory }\end{array}$ \\
\hline
\end{tabular}

Source: Adapted from table of content in JAMS, JOM, JMR, JCR, \& MT (2019 \& 2020) 
The result and finding of this study has been categorized into three sections as the focus of analysis. The sections are trend of research model, trend of data collection method, and trend of data analysis method. Each analysis will be describing the research trends before COVID-19 outbreak which focusing to publication in first semester 2020 and compared to articles published in 2019. Descriptive statistic will be shown in the table to express the comparison between those years and to explain the trends of research methodologies. Perhaps this comparison will be insightful for developing future research.

\section{Trend of Research Model}

Most articles published in JCR, JMR, and JOM are dominated with the experimental studies. Meanwhile, articles published in JAMS and MT are more varies between experimental study, survey study, and literature review. The first trend of research model is an experimental design study. This research method is commonly used by researchers to have deep understanding on the causal relations between variables. Therefore, experimental research is arguably stronger in predicting the behaviour of the respondent (Brunk, 1958). The depth of analysis in this methodology is preferred by most journals. Based on the data in table 4, between 2019 and 2020, experimental study is still named as most popular research model in the marketing journals.

The implementation of experimental study must be aligned with the research design to ensure the best fit of the result. There are several type of experiment designs which researchers should correlate to their research questions and problem statement. There are field experiment and lab experiment, also between subject and within subject experiment, and the quasi experimental study (Sekaran \& Bougie, 2011). Some interesting article which use experimental study in first semester of 2020 are the impact of unprofitable customer on shareholder value (Feng et al., 2020), price promotions cause impatience (Shaddy \& Lee, 2020), and social augmented reality in the marketplace (Hilken et al., 2020).

Table 4. Trend of Research Model

\begin{tabular}{clcccc}
\hline \multirow{2}{*}{ No } & \multicolumn{2}{c}{ Research Model } & \multicolumn{2}{c}{$\mathbf{2 0 2 0}$} & \multicolumn{2}{c}{$\mathbf{2 0 1 9}$} \\
\cline { 3 - 6 } & Number & Percentage & Number & Percentage \\
\hline 1 & $\begin{array}{l}\text { Literature Review (Document, } \\
\text { meta-analysis) }\end{array}$ & 31 & $42 \%$ & 19 & $26 \%$ \\
\hline 2 & Experimental Study & 34 & $47 \%$ & 23 & $32 \%$ \\
\hline 3 & $\begin{array}{l}\text { Qualitative Study (interview, } \\
\text { Observation) }\end{array}$ & 3 & $4 \%$ & 19 & $26 \%$ \\
\hline 4 & Survey/Questionnaire & 5 & $7 \%$ & 12 & $16 \%$ \\
\hline & Total (N) & 73 & $100 \%$ & 73 & $100 \%$ \\
\hline
\end{tabular}

Source: Based on Author's Own Research

Second trend of research model in first semester of 2020 is literature review, which could be systematic literature review or meta-analysis papers. The number of literature review papers in 2020 is significantly increasing compared with 2019. Those number indicate that literature review papers have a good opportunity to be published in those most influential marketing journals.

Systematic literature review is an analysis of content from previous publication which based on qualitative data, meanwhile meta-analysis is literature analysis which based on its quantitative data (Davis et al., 2014; Johnston et al., 2018; Snyder, 2019). 
There are three significant differences in literature review articles which are those papers focusing on domain analysis, theory focus analysis, and methodology focus analysis (Hulland \& Houston, 2020). Those three typical literature review papers are subjected to be concerned for authors to develop their literature review analysis. In conducting literature review, author should focus on specific topic to ensure the depth and rigor of the analysis (Palmatier et al., 2018).

One of interesting literature review in first semester of 2020 is a study on theory in use (TIU) approach in building marketing theory (Zeithaml et al., 2020). The author is comparing TIU with other inductive and deductive methodology in building construct and proposition for developing the marketing theories. Another example of systematic literature review is a study of transparency of behaviour based pricing (BBP) (X. Li et al., 2020). This literature review develops a model in measuring the BBP in firms with two approaches, with or without transparency to the customer. Those studies are example on the literature review papers which have been published in the first semester of 2020 which have rigor and depth of analysis. Therefore, based on the data, author argues that literature review study will be also a further trend to be developed especially regarding the COVID-19 topics and its relation to the marketing science.

Another interesting finding in Table 4 shows that qualitative study is less popular in first semester of 2020. There are only three papers which implement qualitative methodology in their researches, which are ethnography study in collective reflexivity in social marketing (Kariippanon et al., 2020), portable technology and multidomain energy practices (Robinson \& Arnould, 2020), and freedom and regulation in a market-friendly megachurch (Yip \& Ainsworth, 2020). Those articles are published in Marketing Theory, a journal where qualitative study is also preferred to be published.

\section{Trend of Data Collection Method}

The research design will be determining the data collection method in the study. The variety of sampling technique in the research design is also interesting to be further analysed. There are three approaches of data collection method in experimental study, which are based on Purposive Sampling, Random Assignment, and also Amazon Mechanical Turk (MTurk) technique. Purposive or judgement sampling is a nonprobability sampling which categorizing respondent into several attributes based on the research design. Purposive sampling technique is requiring information from special or specific targets or groups of people on some rational basis (Sekaran \& Bougie, 2011). This means that the findings from the study of the sample cannot be confidently generalized to the population (Yang et al., 2006).

Based on data in Table 5, purposive sampling is the most used in the research between 2019 and 2020. In the first semester of 2020, the use of purposive sampling is relatively higher than other sampling methods. This sampling method could be found in some literature review study, experimental study, and other qualitative studies. Hence, this non-probability sampling is preferably used by researchers because it gives the ease of data collection method and also convenience to some conditions during the research processes.

Table 5. Trend of Sampling Technique

\begin{tabular}{cccccc}
\hline \multirow{2}{*}{ No } & \multirow{2}{*}{ Sampling Technique } & \multicolumn{2}{c}{$\mathbf{2 0 2 0}$} & \multicolumn{2}{c}{$\mathbf{2 0 1 9}$} \\
\cline { 3 - 6 } & & Number & Percentage & Number & Percentage \\
\hline 1 & Purposive/Judgement Sampling & 33 & $45 \%$ & 28 & $38 \%$ \\
\hline 2 & MTurk & 27 & $37 \%$ & 19 & $26 \%$ \\
\hline 3 & Random Assignment & 6 & $8 \%$ & 9 & $12 \%$ \\
\hline
\end{tabular}




\begin{tabular}{cccccc}
4 & Others & 7 & $10 \%$ & 17 & $23 \%$ \\
\hline & Total (N) & 73 & $100 \%$ & 73 & $100 \%$ \\
\hline & & \multicolumn{4}{c}{ Source: Based on Author's Own Research }
\end{tabular}

The second data collection method which also popular in the research design in first semester of 2020 is the MTurk method. MTurk is an online platform which developed by Amazon which gathered researchers and respondents in to an online platform. As a crowdsourcing, MTurk proposes a financial benefit to respondents who are finishing the tasks which have been given to their online accounts. Obviously, the source of the money are coming from the researchers which provide the task as respondent in the research. MTurk will be randomly assigning respondents based on the criteria which needed by the researchers. This crowdsourcing platform will be helping researchers in maintaining time and cost in implementing their research. While in conventional method, data collection should be done manually which need more time and money. However, by using this crowdsourcing platform, the data collection method could be done easier and more convenience (Kees et al., 2017).

The use of MTurk is also debatable among the researchers and academicians. The use of online respondent in MTurk platform is raising the validity and reliability issues. However, some researchers have been discussed this issue in their research findings. Kees et al (2017) measured the effectiveness of MTurk which compared with the conventional sampling in experimental studies. The research applied four studies, which are a study using MTurk student sampling, MTurk professional sampling, conventional student sampling, and conventional professional sampling. Result shows that MTurk sampling method has a comparable credibility with the conventional sampling methods (Kees et al., 2017).

The use of MTurk platform is also believed that it will be decreasing a cost of the research. Therefore many researchers are using this data collection method (Anson, 2018). The use of MTurk as the alternative sampling technique in experimental study has been also compared with other similar online platform. Qualtrics with its 'Qbus" sampling is also providing the crowdsourcing for supporting any experimental studies. However, based on the cost and its efficiency, MTurk respondents are more effective in finishing the more complete task comparing than other platform (Anson, 2018).

However, some researchers who use MTurk sampling method should be always considering about the two issues (Hunt \& Scheetz, 2019). First, is the process to access participants who are really met with the qualification of the research. There are plenty of workers from around the world who participate in MTurk platform, since this is a crowdsourcing online platform. Therefore, researchers should really understand about how MTurk works and how to find the relevance respondents. Second consideration is about the validation of data collected. Researchers who used MTurk as their sampling method should consider to the data validation once data has been collected (Hunt \& Scheetz, 2019).

Hence, the use of MTurk in marketing research, especially in the experimental study on consumer behaviour is commonly used by various researchers. Moreover, MTurk sampling method is also a reliable sampling technique for high quality researches which published in the reputable international journals. The ease of use and its cost efficiency will be always the interesting factors for the researchers. Moreover, after COVID-19 pandemic, the physical interaction between researchers and respondent are potentially substituted by using online platform. Therefore, MTurk and other similar 
online platform will be preferred as the new trend of data collection method in the marketing researches.

\section{Trend of Data Analysis Method}

In the last category of analysis, this study is trying to describe the data analysis which used in the articles. In this literature reviews study, there are several popular data analysis methods which have been applied in first semester of 2020. Although quantitative data analysis is more popular than qualitative analysis, however, some conceptual papers and literature review articles were analysed using qualitative approach. Hence, in the Table 6, author has categorized three most popular data analysis methods which have been implemented by the researchers in first semester of 2020 and 2019.

Table 6. Trend of Data Analysis Method

\begin{tabular}{rlrccc}
\hline \multirow{2}{*}{ No } & \multirow{2}{*}{ Data Analysis Method } & \multicolumn{2}{c}{$\mathbf{2 0 2 0}$} & \multicolumn{2}{c}{$\mathbf{2 0 1 9}$} \\
\cline { 3 - 6 } & & Number & Percentage & Number & Percentage \\
\hline 1 & ANOVA & 31 & $42 \%$ & 16 & $22 \%$ \\
\hline 2 & Regression & 28 & $38 \%$ & 36 & $49 \%$ \\
\hline 4 & Qualitative Data Analysis & 14 & $19 \%$ & 21 & $29 \%$ \\
\hline \multicolumn{2}{r}{ Total (N) } & 73 & $100 \%$ & 73 & $100 \%$ \\
\hline & & \multicolumn{4}{c}{ Source: Based on Author's Own Research }
\end{tabular}

In the quantitative data analysis, there are two popular methodologies used which are regression and ANOVA test. Both methodologies are applied based on the purpose and research model which have been developed by the researchers. Both analysis methods are aimed to conduct hypothesis testing in several concept related to the variables in the research model. Regression is used to test the correlation between independent variables and one dependent variable. Meanwhile, ANOVA test is used to analyse the significant mean of two group of dependent variables (Sekaran \& Bougie, 2011). Hence, both data analysis shows that the research model in the first semester of 2020 are using several combinations of multiple independent and dependent variables.

Some example such as experiment study on the secrecy effect of woman's consumption (Rodas \& John, 2020) is used eight experimental designs. Although consisted of eight different studies, the analysis method which applied in this research is only ANOVA test. Meanwhile, another research about identity relevance influence product usage (Sheehan \& Dommer, 2020) were using six experimental studies in their research design. In this experiment, the author use four different data analysis methods which are regression test, ANOVA test, bootstrap analysis, and Hayes' process mediation analysis. Therefore, the more complex of the research model, the more comprehensive the data analysis would be applied.

In the qualitative method, there are several approach of data analysis could be applied such as content analysis, context analysis, and meta-analysis. In the conceptual paper and literature review articles, the use of content analysis and meta-analysis are commonly applied to summarize the result of the studies. Content analysis is the method in interpreting the textual data into several conclusion based on the observation to recorded data from newspaper, documents, report, and others (Sekaran \& Bougie, 2011). Meanwhile, context analysis is relating and synthesizing the data interpretation based on the context where or when the data is collected. Understanding context analysis is relatively influenced by the factors in the surrounding culture, 
norms, history, and other social and natural conditions. Meta-analysis is a secondary data analysis which use statistical basis in formulating the result model. In the metaanalysis study, literature review is applied by synthesizing the previous statistical data and summarize the new perspective based on the data. Meta-analysis is an important research approach to measure the consistency of measurement in some topics based on longitudinal data (Hulland \& Houston, 2020). Therefore, although meta-analysis is categorised as literature review study, the analysis could be also measured by using quantitative data analysis such as regression, ANOVA, and others.

\section{Conclusion and Future Research Agenda}

The trend of research methodologies before COVID-19 Outbreak is varies based on its research models, data collection methods, and data analysis methods. There are two popular research designs which popularly applied by the researchers which are experimental study and literature review study. The data collection methods are also divided in to two popular category which are purposive sampling and Amazon Mechanical Turk (MTurk) methodology. Meanwhile, the trend of data analysis method is dominated by three category which are ANOVA test, regression, and qualitative data analysis. These trends of research methodology are also predicted to be developed during and after the COVID-19 pandemic, where the research methodology will be challenged.

\section{Future Research Model and Topics After the Pandemic}

There are two alternatives for researchers to develop their future research agenda which are conducting experimental studies or creating a literature review analysis. There are several ideas on developing the research topics for those studies. Topic on technology in marketing sciences are interesting to be developed. In the first issue of 2020, JAMS published special issue which discussing the effect of technology to the marketing sciences. This special issue provide various interesting articles regarding role of technology in marketing. As an example, an article which discussing the future of social media in marketing (Appel et al., 2020) is interesting to be developed regarding the change of user behaviour during and after COVID-19 pandemic. In this literature review article, Appel et al (2020) has reviewed the role of development in the society and its impact to consumer behavioural changes. The rise of social media users are also influencing the information changes among the society.

Electronic word of mouth (e-WOM) such online review in social media is also an interesting topic to be developed in the future research. This topic could be conducted through literature review study and also through an experimental study. Reich \& Maglio (2020) have been analysed the persuasive impact of online review and their paper has been published in Journal of Marketing. This article concluded that consumers are having higher trust to online reviewer who has previous mistake in purchasing an item. It is believed that the review given by this type of consumer will be more accountable and based on their own experiences (Reich \& Maglio, 2020). Another research regarding social media in marketing is also developed by Li and Xie (2020) in Journal of Marketing Research. In this article, both authors have been analysing the impact of image content in social media effectiveness and engagement. This study concluded that image content has positive and high impact to the engagement in the social media platform, especially Twitter and Instagram. Image content with a better quality will be better in engaging the audiences (Y. Li \& Xie, 2020). 
Related to the COVID-19 outbreak, the research agenda regarding social media and marketing sciences could be also developed after the rise of social media usage during the lockdown and work from home situation in many countries. Social media has a big role in our social life. As research in Malaysia shows that during the lockdown, the performance of e-business and online market is increasing (Hasanat et al., 2020). The research argues that during the pandemic where physical activities is limited, the business activity through online platform were increasing. Therefore, online shopping and e-business are performing a positive growth since the outbreak.

Another issue regarding social media development during the COVID-19 pandemic is about the role of social media in spreading misinformation and hoax messages among the users. Research in Iran have concluded that there are several misinformation about COVID-19 pandemic which have been spreading out in the whole country (Bastani \& Bahrami, 2020). This research shows that the usage of social media in information exchange during a crisis is really important and need to be well managed by the authority. Therefore, the role of health practitioners are needed to clarify those misinformation.

In the Table 7, author is proposing several research questions which could be developed to the future research agenda.

Table 7. Proposed Research Agenda in Marketing After COVID-19 Pandemic

\begin{tabular}{|c|c|c|c|c|}
\hline Research Dom & & Research Question & & Research Design \\
\hline \multirow{8}{*}{$\begin{array}{l}\text { The Role of } \\
\text { Social Media } \\
\text { After the } \\
\text { COVID-19 } \\
\text { Pandemic }\end{array}$} & & $\begin{array}{l}\text { What is the impact of social media in } \\
\text { online business during COVID-19 }\end{array}$ & & $\begin{array}{l}\text { Experimental } \\
\text { Study }\end{array}$ \\
\hline & & outbreak? & & Metว-A \\
\hline & & How does social media promote health & & Study \\
\hline & & $\begin{array}{l}\text { campaign auring cuviD-19 panaemic! } \\
\text { Why Kev Oninion Leader (influencer) }\end{array}$ & 3. & Systematic \\
\hline & & viny hey upinion Leader (Injiuencer) & & Liter \\
\hline & & promoting social distancing during & & Review \\
\hline & & COVID-19 outbreak? & & \\
\hline & & $\begin{array}{l}\text { endorser in the online business } \\
\text { development before and after } \\
\text { pandemic? }\end{array}$ & 4. & $\begin{array}{l}\text { Experimental } \\
\text { Study }\end{array}$ \\
\hline \multirow{4}{*}{$\begin{array}{l}\text { Social } \\
\text { Marketing \& } \\
\text { Cause-related } \\
\text { Marketing in the } \\
\text { pandemic } \\
\text { situation }\end{array}$} & & & \multirow{2}{*}{5.} & \\
\hline & & pandemic, is it really ethical? & & Literature \\
\hline & & Does Corporate Social Responsibility & & Review \\
\hline & & $\begin{array}{l}\text { programs during the pandemic have } \\
\text { causal impact to the brand image? }\end{array}$ & 6. & $\begin{array}{l}\text { Experimental } \\
\text { Study }\end{array}$ \\
\hline
\end{tabular}

Source: Based on Author's Own Research

The role of cause-related marketing as Chang \& Chu (2020) argued in their research will be potentially different in its implementation in the context of COVID-19 pandemic. Cause-related marketing is predicted to have positive impact to the consumer purchasing behaviour. Consumer which purchase a product after exposed with the cause-related marketing program, will have a prosocial value while purchasing the product (Chang \& Chu, 2020). Hence, the implementation of cause-related marketing in a product strategy will enhance the engagement with the customer. However, after the COVID-19, this hypothesis will be challenged, since the prosocial 
value is also questionable during the crisis in the pandemic situation. Therefore, further empirical study is needed to analyse this proposition.

\section{Trends of Data Collection Method After the Pandemic}

Trend of research methodology which have been summarized in this study will be interesting to develop the future research agenda. Beside the development of research model and topics, researchers should also design their research methodology in an effective research plan. What kind of data collection methods which popular after COVID-19 outbreak? Data collection through online platform will be preferred after the pandemic. The barriers on collecting data in the field study will be challenging since the social and physical distancing are applied during and after the pandemic. Therefore, online platform such MTurk will be more preferred in the future research methodology. While in conventional research where data collection method should be done manually, by using crowdsourcing platform such MTurk, the sampling method could be done easier and more convenience for researchers and also for the respondents.

\section{Trends of Data Analysis Method After the Pandemic}

Although there are three popular data analysis methods in the first semester of 2020, the trend of data analysis after pandemic could not be easily predicted. The use of data analysis methodology is strongly related to the number of variables in the model of research design. Therefore, there is no specific method in predicting any data analysis method that could be popular in the near future. However, based on the previous trend in 2019 and first semester of 2020, author argues that Regression, ANOVA test, and Qualitative Data Analysis will be also implemented in many research agendas after the pandemic.

\section{Discussion \& Limitation}

Although this study has conducting integrative literature review on 146 articles which published in the most influencing marketing journals, the limitation of its methodology and depth of analysis might be presence. This study is implementing integrative literature review which aimed to summarize the findings and conclude the analysis to develop future research agenda. However, the limitation of articles and journal sources might be impacting the generalization of the results. Perhaps in the future research, the variety of articles and journal sources could be expanded and developed.

\section{Acknowledgement}

Author would like to thank Dr. Rizal Edy Halim, Regina Deka, Vita Nurul, Iqbal Pratama, and Artha Kusuma from PPIM University of Indonesia regarding their advice to this research. The appreciation is also delivered to the Dean and Lecturers at Sekolah Tinggi Manajemen PPM and also to the team of LPDP RI for their materials and moral support.

\section{References}

Agoston, S., \& Dima, A.M. (2012). Modeling intellectual capital using Analytic Hierarchy Process (AHP). Proceedings of the $4^{\text {th }}$ European Conference on Intellectual capital, Arcada University of Applied Sciences, Helsinki, Finland, 23-24 April 2012, pp. 1-9.

Anson, I. G. (2018). Taking the time? Explaining effortful participation among low-cost online survey participants. Research and Politics, 5(3). https://doi.org/10.1177/2053168018785483

Appel, G., Grewal, L., Hadi, R., \& Stephen, A. T. (2020). The future of social media in 
marketing. Journal of the Academy of Marketing Science, 48(1), 79-95. https://doi.org/10.1007/s11747-019-00695-1

Bastani, P., \& Bahrami, M. A. (2020). COVID-19 Related Misinformation on Social Media: A Qualitative Study from Iran. Journal of Medical Internet Research, 22(3), 12-19. https://doi.org/10.2196/18932

Bratianu, C., Prelipcean, G., \& Bejinaru, R. (2020). Exploring the latent variables which support SMEs to become learning organizations. Management \& Marketing. Challenges for the Knowledge Society, 15(2), 154-171.

Brunk, M. E. (1958). Use of Experimental Design in Marketing Research. Journal of Farm Economics, 40(5), 1237-1246.

Carlsson-Szlezak, P., Reeves, M., \& Swartz, P. (2020). What coronavirus could mean for the global economy. Harvard Business Review, 12.

Chabowski, B. R., Mena, J. A., \& Gonzalez-Padron, T. L. (2011). The structure of sustainability research in marketing, 1958-2008: A basis for future research opportunities. Journal of the Academy of Marketing Science, 39(1), 55-70. https://doi.org/10.1007/s11747-010-0212-7

Chang, C. T., \& Chu, X. Y. (Marcos). (2020). The give and take of cause-related marketing: purchasing cause-related products licenses consumer indulgence. Journal of the Academy of Marketing Science, 48(2), 203-221. https://doi.org/10.1007/s11747019-00675-5

Craven, M., Singhal, S., \& Wilson, M. (2020). COVID-19 : Briefing note ,. McKinsey \& Company.

Dahlstrom, R., Nygaard, A., \& Crosno, J. L. (2008). Strategic, metric, and methodological trends in marketing research and their implications for future theory and practice. Journal of Marketing Theory and Practice, 16(2), 139-152. https://doi.org/10.2753/MTP1069-6679160204

Davis, J., Mengersen, K., Bennett, S., \& Mazerolle, L. (2014). Viewing systematic reviews and meta-analysis in social research through different lenses. SpringerPlus, 3(1), 19. https://doi.org/10.1186/2193-1801-3-511

de Caro, F., Hirschmann, T. M., \& Verdonk, P. (2020). Returning to orthopaedic business as usual after COVID-19: strategies and options. Knee Surgery, Sports Traumatology, Arthroscopy, 28(1), 1-6. https://doi.org/10.1007/s00167-020-06031-3

Feng, H., Morgan, N. A., \& Rego, L. L. (2020). The impact of unprofitable customer management strategies on shareholder value. Journal of the Academy of Marketing Science, 48(2), 246-269. https://doi.org/10.1007/s11747-019-00686-2

Franceschini, F., Maisano, D., \& Mastrogiacomo, L. (2015). Influence of omitted citations on the bibliometric statistics of the major manufacturing journals. Scientometrics, 103(3), 1083-1122. https://doi.org/10.1007/s11192-015-1583-9

Hasanat, M. W., Hoque, A., Shikha, F. A., Anwar, M., Abdul Hamid, A. B., \& Hon Tat, H. (2020). The Impact of Coronavirus (Covid-19) on E-Business in Malaysia. Asian Journal of Multidisciplinary Studies, 3(1), 1-6.

Hilken, T., Keeling, D. I., de Ruyter, K., Mahr, D., \& Chylinski, M. (2020). Seeing eye to eye: social augmented reality and shared decision making in the marketplace. Journal of the Academy of Marketing Science, 48(2), 143-164. https://doi.org/10.1007/s11747-019-00688-0

Huberman, A., \& Miles, M. (2012). Understanding and Validity in Qualitative Research. In The Qualitative Researcher's Companion. https://doi.org/10.4135/9781412986274.n2

Hulland, J., \& Houston, M. B. (2020). Why systematic review papers and meta-analyses 
matter: an introduction to the special issue on generalizations in marketing. Journal of the Academy of Marketing Science, 48(3), 351-359.

https://doi.org/10.1007/s11747-020-00721-7

Hunt, N. C., \& Scheetz, A. M. (2019). Using MTurk to distribute a survey or experiment: Methodological considerations. Journal of Information Systems, 33(1), 43-65. https://doi.org/10.2308/isys-52021

Johnston, W. J., Le, A. N. H., \& Cheng, J. M. S. (2018). A meta-analytic review of influence strategies in marketing channel relationships. Journal of the Academy of Marketing Science, 46(4), 674-702. https://doi.org/10.1007/s11747-017-0564-3

Kariippanon, K., Gordon, R., Jayasinghe, L., \& Gurruwiwi, G. (2020). Collective reflexivity in social marketing through ethnographic film-making: The Yolngu story of tobacco in Yirrkala, Australia. Marketing Theory, 20(1), 123-143. https://doi.org/10.1177/1470593119870215

Kees, J., Berry, C., Burton, S., \& Sheehan, K. (2017). An Analysis of Data Quality: Professional Panels, Student Subject Pools, and Amazon's Mechanical Turk. Journal of Advertising, 46(1), 141-155. https://doi.org/10.1080/00913367.2016.1269304

Li, X., Li, K. J., \& Wang, X. (2020). Transparency of Behavior-Based Pricing. Journal of Marketing Research, 57(1), 78-99. https://doi.org/10.1177/0022243719881448

Li, Y., \& Xie, Y. (2020). Is a Picture Worth a Thousand Words? An Empirical Study of Image Content and Social Media Engagement. Journal of Marketing Research, 57(1), 1-19. https://doi.org/10.1177/0022243719881113

Maxwell, J. A., \& Reybold, L. E. (2015). Qualitative Research. In International Encyclopedia of the Social \& Behavioral Sciences: Second Edition. https://doi.org/10.1016/B978-0-08-097086-8.10558-6

Nicolas, C., Valenzuela-Fernández, L., \& Merigó, J. M. (2020). Research Trends of Marketing: A Bibliometric Study 1990-2017. Journal of Promotion Management, 26(3), 1-30. https://doi.org/10.1080/10496491.2020.1729315

Palmatier, R. W., Houston, M. B., \& Hulland, J. (2018). Review articles: purpose, process, and structure. Journal of the Academy of Marketing Science, 46(1), 1-5. https://doi.org/10.1007/s11747-017-0563-4

Reich, T., \& Maglio, S. J. (2020). Featuring Mistakes: The Persuasive Impact of Purchase Mistakes in Online Reviews. Journal of Marketing, 84(1), 52-65. https://doi.org/10.1177/0022242919882428

Robinson, T. D., \& Arnould, E. (2020). Portable technology and multi-domain energy practices. Marketing Theory, 20(1), 3-22. https://doi.org/10.1177/1470593119870226

Rodas, M. A., \& John, D. R. (2020). The secrecy Effect: Secret Consumption Increases Women's Product Evaluations and Choice. Journal of Marketing Research, 46(6), 93-110. https://doi.org/10.1111/))

Sekaran, U., \& Bougie, R. (2011). Business Research Methods: A skill-building approach. In Wiley. https://doi.org/http://as.wiley.com/WileyCDA/WileyTitle/productCd111994225X.html\#

Shaddy, F., \& Lee, L. (2020). Price Promotions Cause Impatience. Journal of Marketing Research, 57(1), 118-133. https://doi.org/10.1177/0022243719871946

Sheehan, D., \& Dommer, S. L. (2020). Saving your self: How identity relevance influences product usage. Journal of Consumer Research, 46(6), 1076-1092. https://doi.org/10.1093/jcr/ucz037

Snyder, H. (2019). Literature review as a research methodology: An overview and guidelines. Journal of Business Research, 104(March), 333-339. 
https://doi.org/10.1016/j.jbusres.2019.07.039

Sorescu, A., Warren, N. L., \& Ertekin, L. (2017). Event study methodology in the marketing literature: an overview. Journal of the Academy of Marketing Science, 45(2), 186-207. https://doi.org/10.1007/s11747-017-0516-y

Stojanovski, J., \& Pehar, F. (2014). Multiple Bibliometric Indicators Approach to Croatian Open Access (OA) Journals. Libraries in the Digital Age (LIDA) Proceedings.

Yang, Z., Wang, X., \& Su, C. (2006). A review of research methodologies in international business. International Business Review, 15(6), 601-617. https://doi.org/10.1016/j.ibusrev.2006.08.003

Yip, J., \& Ainsworth, S. (2020). You need 'help for the journey': Freedom and regulation in a 'market-friendly' megachurch. Marketing Theory, 20(1), 103-121. https://doi.org/10.1177/1470593119856654

Zeithaml, V. A., Jaworski, B. J., Kohli, A. K., Tuli, K. R., Ulaga, W., \& Zaltman, G. (2020). A Theories-in-Use Approach to Building Marketing Theory. Journal of Marketing, 84(1), 32-51. https://doi.org/10.1177/0022242919888477 